\title{
Assessment of Groundwater Pollution Vulnerability, Hazard and Risk in a Semi-Arid Region
}

\author{
Nadjib Haied ${ }^{1 *}$, Samira Khadri², Atif Foufou' ${ }^{1}$, Mohamed Azlaoui ${ }^{3}$, \\ Salah Chaab ${ }^{4}$, Nabil Bougherira ${ }^{5}$
}

1 Earth and Universe Sciences Department, Ziane Achour University of Djelfa, Djelfa 17000, PO Box 3117, Algeria

2 Biological Sciences Department, Ziane Achour University of Djelfa, Djelfa 17000, PO Box 3117, Algeria

3 Department of Hydraulic, Ziane Achour University of Djelfa, Djelfa 17000, PO Box 3117, Algeria

4 Geology Laboratory, Badji Mokhtar-Annaba University, Annaba 23000, PO Box 12, Algeria

5 Water Resources and Sustainable Development Laboratory, Badji Mokhtar-Annaba University, Annaba 23000, PO Box 12, Algeria

* Corresponding author's email: haiednajib@gmail.com

\begin{abstract}
The Mio-plio-quaternary aquifer of the Djelfa Syncline is part of a region in Algeria which is characterized by the lack of surface water resources and located in a semi-arid climate. Since alluvial aquifers, and among them our aquifer, are the most vulnerable because of thier direct exposure to the pollution caused by the infiltrated pollutants, this work focused on the assessement of groundwater pollution vulnerability, hazard and risk. Thus, several methods were used; for this purpose, such as the DRASTIC and WQI methods mapped using a GIS. The results obtained clearly show a low to moderate vulnerability. The DRASTIC model and its validation based on the correlation with WQI revealed a low correlation $\left(\mathrm{WQ}_{\mathrm{I}} \mathrm{vs} \mathrm{D}_{\mathrm{I}}: 0.221\right)$. Since the vulnerability model does not match with the groundwater quality, pollution risk was assessed by combining vulnerabilty and hazard (i.e, water quality). The risk map illustrated three levels ranging from low to high risk. This map should be helpful in decision making and groundwater management through avoiding high risk areas.
\end{abstract}

Keywords: Mio-plio-quaternary aquifer, Djelfa syncline, DRASTIC, WQI, GIS, pollution risk.

\section{INTRODUCTION}

Groundwater is considered as the most solicited resource in semi-arid regions to supply the growing needs for drinking water, agriculture and industry. However, the decrease in aquifer reserves caused by the imbalance between groundwater recharge and extraction aggravates the problems related to the pollution of this resource. The water resources pollution has gained a universal interest due to anthropogenic activities [Allechy et al., 2016]. Furthermore, the climate change causing drought events due to growing global temperatures can increase the vulnerability of water resources [Taabni and El Jihad, 2012].
Groundwater contamination is caused mainly by pollutants infiltration into the soil sub-strata [Kumar et al., 2015; Foufou et al., 2017]. Probability and severity of contamination is influenced by soil type, depth of the aquifer, weather, season and the recharge rate of an aquifer [Abassi, 1999]. Therefore, the groundwater quality depends on the quality of recharged water, atmospheric precipitation, inland surface water and subsurface geochemical processes [Reza and Singh, 2010; Vasanthavigar et al., 2010]. Hence, the prevention and the protection of groundwaterrequire a water quality monitoring program, such as the assessment of the vulnerability and the quality of groundwater respectively. To this end, several methods have been developed all over the world. 
Classified into process-based simulation models, statistical methods; and overlay and index methods [NRC, 1993], the groundwater vulnerability is considered as a useful tool to identify the water sensitivity to contamination by distinguishing the vulnerability extents [Huan et al. 2012; Boufekane and Saighi, 2018]. The most used techniques to identify the vulnerability are overlay index methods and among them DRASTIC method [Aller et al., 1987] based on the superposition of some sub-indices. Moreover, the uncertainty of aquifer vulnerability assessment due to insufficient representation of some vulnerability parameters [Babiker et al., 2007] also the vulnerabilty model validation [Heiß et al., 2020] oblige to evaluate the water quality. Therefore, several water quality indices have been developped for estimating the overall water quality within a particular area promptly and efficiently [Bharti and Katyal, 2011] based on the comparison of some chemical parameters to standards to give a single value to the water quality [Abbasi, 1999; Khan et al., 2003]. To this end, the water quality index WQI proposed by Brown et al. [1970] was used.

The main objectives of this paper were: (i) the vulnerability assessment of the mio-plio-quaternary aquifer located in a semi-arid region using the DRASTIC model, (ii) its validation using water quality index (WQI), and (iii) finally, since the risk is defined as the combination of hazard and vulnerability [Wisner et al. 2004], the evaluation of pollution risk was done. A risk map was realized in which risk is defined as the product of hazard (i.e., water quality) and vulnerability.

\section{STUDY AREA}

\section{Geographical and geological context}

The study area occupies the central part of the Saharian Atlas precisely, Ouleds Nail's mountains of Djelfa northern part, it is located at $300 \mathrm{~km}$ south of Algiers (Fig. 1), at $110 \mathrm{~km}$ North of Laghouat city and at $110 \mathrm{~km}$ southwest of Boussaada. It stretches $80 \mathrm{~km}$ long and $25 \mathrm{~km}$ wide in maximum, surrounded by the Djebels: Senalba, Djellal Gharbi and Djellal Chargui. It is limited by $2^{\circ} 44^{\prime}$ and $3^{\circ} 25^{\prime}$ East longitude and $34^{\circ} 24^{\prime}$ and $34^{\circ} 59^{\prime}$ North latitude.

The Mio-plio-quaternary aquifer, which is part of Djelfa syncline, belongs mainly to the Zahrez watershed coded 17 (Fig. 1), more exactly, in wadi Djelfa-Hadjia and Daiet Mefiteg sub-basins coded 17-02 and 17-04 respectively.

The lithostratigraphy of Djelfa syncline (Fig. 2) description based on the previous research [Chibane et al., 2010; Chibane and Ali-Rahmani, 2015; Ali-Rahmani et al., 2016] allowed determining the existing geological deposits. The Triassic is formed by sandstone clays, schists and marls with some inclusions of conglomerates. It outcrops in the Salt Rock rich in gypsum or anhydrite and potassium salts. The Cretaceous formations are represented by limestones, marls and sandstones. The Neocomian outcrops are clayeysandstone formations, covered by decametric beds of dolomitic limestones and sandstone limestones and limestones. The Barremian is made by sandstone and sandstone clays alternations. The Aptian formations are marls constituting the substratum of the massive fine sandstone aquifer of the Lower Albian. The lower part of the albian is formed by fine massive sandstone interspersed by clay passes. Its upper part is made by alternating limestones and marls. Both parts are of hydrogeological interest. The Cenomanian is represented by marly formations with sometimes clays and thin limestone beds intercalations in the summit. The Turonian outcrops all around the Syncline, at the top, as hard limestones fissured and dissolved which implies their hydrogeological interest. In the middle part, a marly set with organic limestone intercalations is found. This stage ends with limestone in platelets and gypsum. The Senonian outcrops as limestone with marly curves alternation. Its lower limit is materialized by alternating marly limestone and the upper limit is undetermined. The Mio-plioquaternary is formed by conglomerates resulting from torrential deposits or wadis channels. It constitutes the surface reservoir of the region the most requested by the peasants; its thickness is very variable (2 to $50 \mathrm{~m}$ ) [Chibane et al., 2010], hence the interest of this work.

\section{Hydrology and hydrogeology}

The study area has a continental climate of semi-arid type with cold winter, and a hot and dry summer. Precipitation during the period (1975-2018) was relatively small and about $308.24 \mathrm{~mm} /$ year, the average annual of temperature was $14.73{ }^{\circ} \mathrm{C}$. Potential evapotranspiration (PET) and actual evapotranspiration (AET) determined by the Thornthwaite method 

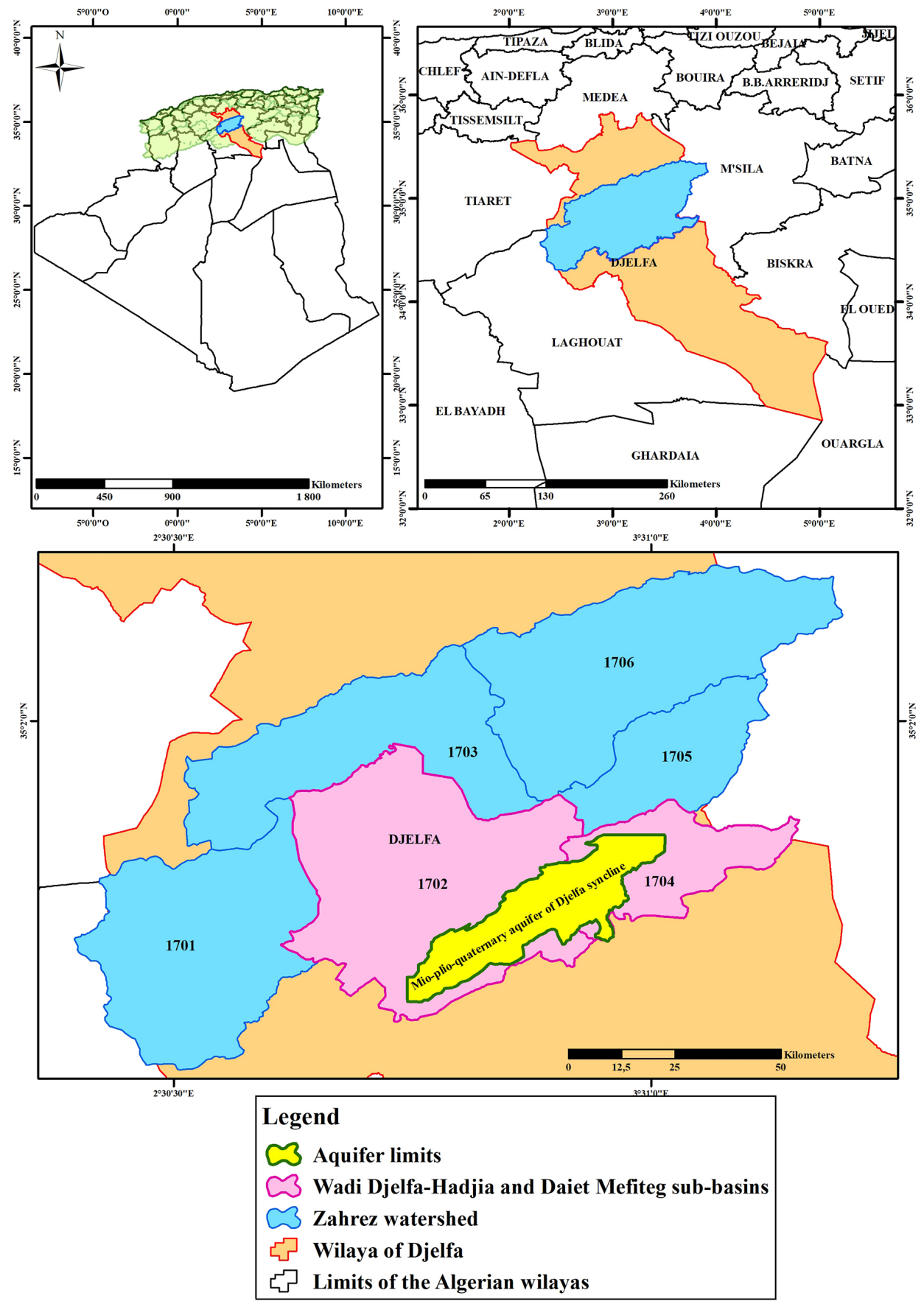

Figure 1. Study area geographic location

are $824.7 \mathrm{~mm} /$ year and $275.3 \mathrm{~mm} /$ year $(89 \%$ of precipitation), respectively. The runoff (R) estimated by the Tixeront-Berkaloff formula is $14.34 \mathrm{~mm} /$ year, or $5 \%$ of the annual average of rainfall. This value is low but it is admissible. Effective infiltration (Ie) is estimated from the equation of water balance, it is about $20.84 \mathrm{~mm} /$ year, or $7 \%$ of precipitation, which is extremely low.

The hydrogeological formations that are determined in the Mio-plio-quaternary aquifer are clays, limestones, marls and silts with sandstone lenses and conglomerates. It is a heterogeneous aquifer that is located in the central part of the Djelfa syncline, and rests on the Senonian [Chibane B. et al., 2010], in which marly levels ensure the retention of water.

The aquifer is fed by the two flanks of the syncline (Djebel Senalba on the northern flank and Djebel Djellal Chergui and Djellal Gharbi on the southern flank) either by direct runoff or by infiltration via faults.

The piezometric map (Fig. 3) shows that the groundwater flow converges towards the main wadis. The main flow is in the same direction 


\begin{tabular}{|c|c|c|c|}
\hline \multicolumn{2}{|c|}{ Facies and corresponding stage } & Lithostratigraphy & Hydrogeology \\
\hline & $\begin{array}{l}\text { Mio-plio- } \\
\text { quaternary }\end{array}$ & $\begin{array}{l}\text { Sandy silts, limestone crusts, clays, } \\
\text { red marls with sandstoneand } \\
\text { limestone lenses. }\end{array}$ & Permeable. \\
\hline & Senonian & $\begin{array}{l}\text { Alternating limestones and marls } \\
\text { withfrequent gypsum lenses } \\
\text { towards the top. }\end{array}$ & Low permeability. \\
\hline & Turonian & $\begin{array}{l}\text { Hard and cracked limestones, marls } \\
\text { with intercalations of organic } \\
\text { limestone levels. }\end{array}$ & $\begin{array}{l}\text { Very productive karst } \\
\text { type. }\end{array}$ \\
\hline & Cenomanian & $\begin{array}{l}\text { Limestone at the top and } \\
\text { marls at the base. }\end{array}$ & Permeable at the top. \\
\hline & Albian & $\begin{array}{l}\text { Limestones and marls alternations } \\
\text { in the upper part and massive } \\
\text { sandstones interspersed with clays } \\
\text { in the lower part. }\end{array}$ & Permeable. \\
\hline & Aptian & $\begin{array}{l}\text { Marls and limestones } \\
\text { (dominance of marls). }\end{array}$ & Impermeable. \\
\hline & Barremian & $\begin{array}{l}\text { Alternation of sandstone and } \\
\text { sandstone clays with a frequent } \\
\text { intersecting stratification in } \\
\text { sandstones, there are many joints } \\
\text { and cracks. }\end{array}$ & Permeable. \\
\hline & & Presence of dolomitic and sandstone & Permeable. \\
\hline & Neocomian & $\begin{array}{l}\text { limestones in the upper part and } \\
\text { sandstone clays in the lower part. }\end{array}$ & Impermeable. \\
\hline & Triassic & $\begin{array}{l}\text { Lamellar gypsum, anhydrite, salt, } \\
\text { series of clay sometimes with } \\
\text { evaporites. }\end{array}$ & \\
\hline
\end{tabular}

Figure 2. Lithostratigraphy of Djelfa syncline

as the wadi Djelfa-Hadjia. The piezometric map shows that the underground flow follows a southwest-north-east axis parallel to the syncline orientation axis.

\section{METHODOLOGY}

\section{Vulnerability Assessment}

\section{DRASTIC Method}

The DRASTIC method [Aller et al., 1987] was developed by the US Environmental Protection Agency (EPA) with the aim of assessing the groundwater pollution risks[Knox et al., 1993; Verba and Zaporozec, 1994; Mardhel et al., 2005]. The letters of the DRASTIC acronym refer to the factors: Depth to theWater, Net Recharge, Aquifer Media, Soil Media, Topography, Impact of the Vadose Zone, Hydraulic Conductivity of the aquifer, respectively. Ratings and weights ranging from 1 to 10 and 1 to 5 respectively are assigned to the corresponding parameter, as mentioned in the Table 1.The DRASTIC index is obtained by multiplying the rate of each parameter by its weight and by summing these products:

$$
\begin{gathered}
\text { DRASTIC Index }= \\
=\mathrm{D}_{\mathrm{r}} \cdot \mathrm{D}_{\mathrm{w}}+\mathrm{R}_{\mathrm{r}} \cdot \mathrm{R}_{\mathrm{w}}+\mathrm{A}_{\mathrm{r}} \cdot \mathrm{A}_{\mathrm{w}}+\mathrm{S}_{\mathrm{r}} \cdot \mathrm{S}_{\mathrm{w}}+\mathrm{T}_{\mathrm{r} \cdot \mathrm{T}}+\mathrm{T}_{\mathrm{r}} \cdot \mathrm{I}_{\mathrm{w}}+\mathrm{C}_{\mathrm{r}} \cdot \mathrm{C}_{\mathrm{w}}
\end{gathered}
$$

where: $r$ and $w$ are the corresponding ratings and weights for each parameter.

The DRASTIC vulnerability index is classified by Engel et al. (1996) into four classes (Table 2).

\section{Parameter determination}

Depth to the water (D) was determined by subtracting the altitude of the contour lines and the piezometric levels. The aquifer recharge is ensured by the direct infiltration of the rainfall 


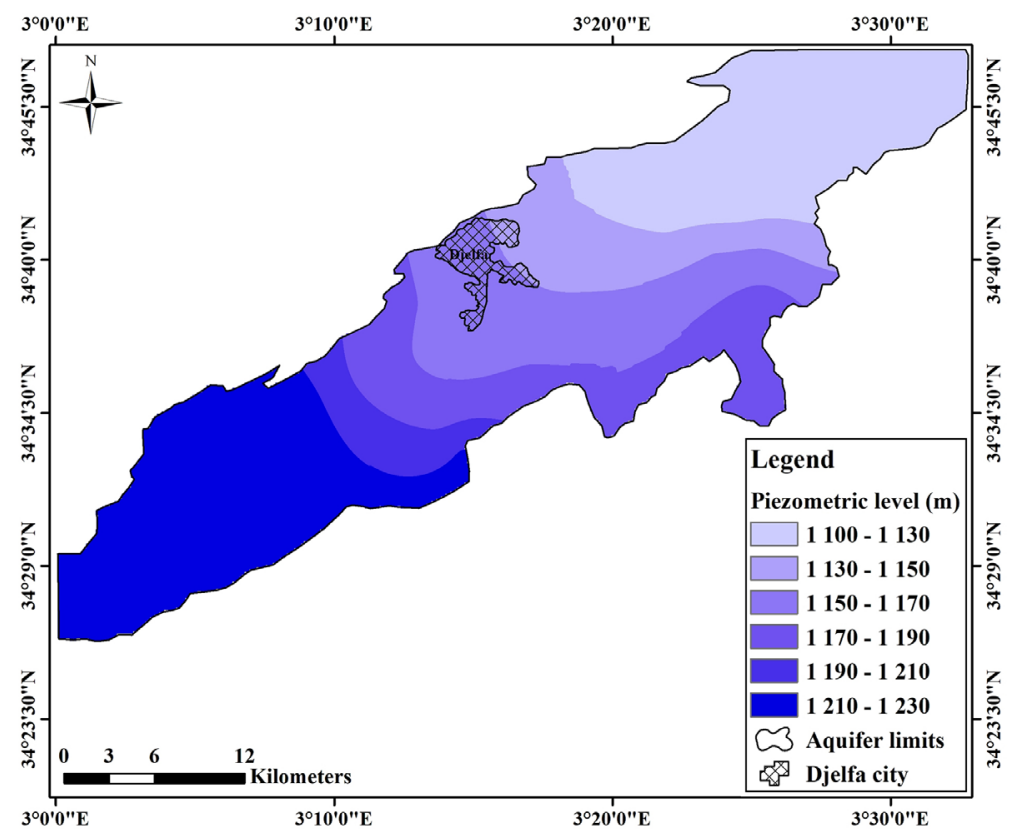

Figure 3.Mio-plio-quaternary aquifer piezometric map (April 2015)

waters which is named effective infiltration; the latter represents the Net Recharge (R). In the investigated case, the effective infiltration was calculated using Thornthwaite method, which yielded a single value $(20.84 \mathrm{~mm})$. Aquifer Media (A) was determined based on the hydrogeological map realized by the National Agency of Hydraulic Resources (French: Agence National des Ressources Hydrauliques). Soil Media (S) parameter data was obtained from a 1:1,500,000 scaled soil map (Soil map of Algeria, Biskra region, 1938). STRM 1 Arc-second [USGS, 2019] as a global digital elevation model with a $30 \mathrm{~m}$ spatial resolution in combination with ArcGIS 10.3 was used to calculate and to realize the slopes map (Topography, T). The geological map and the drilling logs wereused to classify the Impact of the Vadose zone (I). Finally, the Hydraulic Conductivities (C) were determined by using the chart of Freeze and Cherry (1979).

\section{Water Quality Assessment}

\section{Water Quality Index (WQI)}

Water quality index (WQI) was developed by Brown et al. (1970). It is defined as a useful technique of rating communicating the overall quality of water based on individual water quality parameters [Mitra, 1998; Reza and Singh, 2010]. Numerically, WQI summarizes the information from several water quality parameters into a unique value [Krishan et al., 2016].

\section{WQI determination}

Three steps are followed for calculating WQI, [Horton, 1965; Pradhan et al., 2001; Asadi et al., 2007; Dwivedi and Pathak, 2007; Vasanthavigar et al., 2010; Yidana and Yidana, 2010; Ketata et al., 2012]. Firstly, a weight (wi) ranging from 1 to 5 was assigned to the used chemical parameters (pH, TDS, $\mathrm{Cl}, \mathrm{SO}_{4}^{2-}, \mathrm{HCO}_{3}^{-}, \mathrm{NO}_{3}^{-}, \mathrm{Ca}^{2+}, \mathrm{Mg}^{2+}$, $\mathrm{Na}^{+}$and $\mathrm{K}^{+}$) (Table 3). The highest weight (5) has been assigned to such parameters as TDS and $\mathrm{NO}_{3}^{-}$because of their importance in water quality assessment [Srinivasamoorthy et al., 2008].

The lowest weight 1 was assigned to potassium $\left(\mathrm{K}^{+}\right)$due to its insignificant importance in water quality evaluation. Calcium, Magnesium, Sodium, Chloride, Sulfate and Bicarbonate was given a weight ranging from 2 to 4 , according to their importance in the overall quality of drinking water [Ketata et al., 2012]. Secondly, the calculation of the relative weigh (Wi) for each parameter is given by the following equation and listed in (Table 3).

$$
W_{i}=\frac{w_{i}}{\sum_{i=1}^{n} w i}
$$

where: Wi: relative weight, wi: weight of each parameter, $\mathrm{n}$ : parameter number.

Finaly, the quality rating scale (qi) have been computed for each parameter by the ration of the sample concentration to its WHO standard 
Table 1. DRASTIC Rating and Weight Systems [Aller et al., 1987]

\begin{tabular}{|c|c|c|c|c|}
\hline DRASTIC Parameter & Unit (SI) & Range & Rating & Weigt \\
\hline \multirow{7}{*}{ Depth to the water } & \multirow{7}{*}{$\mathrm{m}$} & $0-1.5$ & 10 & \multirow{7}{*}{5} \\
\hline & & $1.5-4.5$ & 9 & \\
\hline & & $4.5-9$ & 7 & \\
\hline & & $9-15$ & 5 & \\
\hline & & $15-22$ & 3 & \\
\hline & & $22.5-30$ & 2 & \\
\hline & & $>30$ & 1 & \\
\hline \multirow{5}{*}{ Recharge } & \multirow{5}{*}{$\mathrm{Mm}$} & $0-50$ & 1 & \multirow{5}{*}{4} \\
\hline & & $50-100$ & 3 & \\
\hline & & $100-180$ & 6 & \\
\hline & & $180-250$ & 8 & \\
\hline & & $>250$ & 9 & \\
\hline \multirow{9}{*}{ Aquifer media } & \multirow{9}{*}{ I } & Massive shale & 2 & \multirow{9}{*}{3} \\
\hline & & Metamorphic/igneous & 3 & \\
\hline & & Weathered metamorphic igneous & 4 & \\
\hline & & Glacial till & 5 & \\
\hline & & Bedded sandsone, limestone & 6 & \\
\hline & & Massive sandsone & 6 & \\
\hline & & Massive limestone, sand and gravel & 8 & \\
\hline & & Basalt & 8 & \\
\hline & & Massive shale & 10 & \\
\hline \multirow{11}{*}{ Soil media } & \multirow{11}{*}{ l } & Thin or absent & 10 & \multirow{11}{*}{2} \\
\hline & & Gravel & 10 & \\
\hline & & Sand & 9 & \\
\hline & & Peat & 8 & \\
\hline & & Shrinking clay & 7 & \\
\hline & & Sandy loam & 6 & \\
\hline & & Loam & 5 & \\
\hline & & Silty loam & 4 & \\
\hline & & Clay loam & 3 & \\
\hline & & Muck & 2 & \\
\hline & & No shrinking clay & 1 & \\
\hline \multirow{5}{*}{ Topography } & \multirow{5}{*}{$\%$} & $0-2$ & 10 & \multirow{5}{*}{1} \\
\hline & & $2-6$ & 9 & \\
\hline & & $6-12$ & 5 & \\
\hline & & $12-18$ & 3 & \\
\hline & & $>18$ & 1 & \\
\hline \multirow{10}{*}{ Impact of the vadose zone } & \multirow{10}{*}{ I } & Confining layer & 1 & \multirow{10}{*}{5} \\
\hline & & Silt/clay & 3 & \\
\hline & & Shale & 3 & \\
\hline & & Limestone & 3 & \\
\hline & & Sandstone & 6 & \\
\hline & & Bedded limestone, sandstone & 6 & \\
\hline & & Sand, gravel and silt & 6 & \\
\hline & & Sand and gravel & 8 & \\
\hline & & Basalt & 9 & \\
\hline & & Karsts limestone & 10 & \\
\hline \multirow{6}{*}{ Conductivity } & \multirow{6}{*}{$\mathrm{m} / \mathrm{s}$} & $4.7 \times 1^{10-7}$ to $4.7 \times 10^{-5}$ & 1 & \\
\hline & & $4.7 \times 10^{-5}$ to $14.7 \times 10^{-5}$ & 2 & \\
\hline & & $14.7 \times 10^{-5}$ to $32.9 \times 10^{-5}$ & 4 & 3 \\
\hline & & $32.9 \times 10^{-5}$ to $4.7 \times 10^{-4}$ & 6 & 0 \\
\hline & & $4.7 \times 10^{-4}$ to $9.4 \times 10^{-4}$ & 8 & \\
\hline & & $>9.4 \times 10^{-4}$ & 10 & \\
\hline
\end{tabular}


Table 2. DRASTIC vulnerability classes [Engel et al., 1996]

\begin{tabular}{|l|c|}
\hline \multicolumn{1}{|c|}{ Vulnerability class } & Vulnerability index \\
\hline Low & $<100$ \\
\hline Moderate & $101-140$ \\
\hline High & $140-200$ \\
\hline Very High & $>200$ \\
\hline
\end{tabular}

Table 3. Weight and relative weight of each chemical parameter [Ketata et al., 2012]

\begin{tabular}{|c|c|c|c|}
\hline $\begin{array}{c}\text { Chemical } \\
\text { Parameters }\end{array}$ & $\begin{array}{c}\text { WHO } \\
\text { Standards (Si) }\end{array}$ & Weight (wi) & $\begin{array}{c}\text { Relative } \\
\text { weight (Wi) }\end{array}$ \\
\hline $\mathrm{pH}$ & 8,5 & 3 & 0.103 \\
\hline $\mathrm{TDS}(\mathrm{mg} /)$ & 500 & 5 & 0.172 \\
\hline $\mathrm{Cl}^{-}(\mathrm{mg} /)$ & 250 & 3 & 0.103 \\
\hline $\mathrm{SO}_{4}{ }^{2-}(\mathrm{mg} /)$ & 250 & 3 & 0.103 \\
\hline $\mathrm{NO}_{3}{ }^{-}(\mathrm{mg} /)$ & 50 & 5 & 0.172 \\
\hline $\mathrm{HCO}_{3}{ }^{-}(\mathrm{mg} /)$ & 120 & 2 & 0.068 \\
\hline $\mathrm{Na}^{+}(\mathrm{mg} /)$ & 200 & 3 & 0.103 \\
\hline $\mathrm{Ca}_{2}{ }^{+}(\mathrm{mg} /)$ & 75 & 2 & 0.068 \\
\hline $\mathrm{Mg}_{2}{ }^{+}(\mathrm{mg} /)$ & 50 & 2 & 0.068 \\
\hline $\mathrm{K}^{+}(\mathrm{mg} /)$ & 12 & 1 & 0.034 \\
\hline & & $\sum \mathrm{wi}=29$ & $\Sigma W \mathrm{Wi}=0.9949$ \\
\hline
\end{tabular}

multiplied by 100 [Ramakrishnaiah et al., 2009; Ketata et al., 2012; Şener et al., 2017]:

$$
q_{i}=\left(\frac{C_{i}}{S_{i}}\right) \times 100
$$

where: $q i$ is the quality rating,

$\mathrm{Ci}$ is the concentration of each parameter in each water sample in $\mathrm{mg} / \mathrm{l}$ and

$\mathrm{Si}$ is the World's Health Organization standards [WHO, 2011] of each chemical parameter in $\mathrm{mg} / \mathrm{l}$.

The sum of SIi values is the Water Quality Index value for each sample, SIivalue must be determined by the given equation:

$$
S I_{i}=W_{i} x q_{i}
$$

where: $S I i$ is the sub-index of ith parameter,

$q i$ is the rating based on concentration of $\mathrm{i}^{\text {th }}$ parameter [25].

The WQI is given by the equation (5):

$$
W Q I=\sum_{i=1}^{n} S I_{i}
$$

Table 4. Groundwater quality classification [Ketata et al., 2012]

\begin{tabular}{|c|c|}
\hline WQI range & Water type \\
\hline$<50$ & Excellent water \\
\hline $50-100,1$ & Good water \\
\hline $100-200,1$ & Poor water \\
\hline $200-300,1$ & Very poor water \\
\hline$>300$ & Unfit for drinking \\
\hline
\end{tabular}

The calculated values of WQI are classified into five categories [Ketata et al., 2012] as mentioned in the Table 4.

\section{RESULTS AND DISCUSSIONS}

\section{Vulnerability index by the DRASTIC Method}

Regarding the DRASTIC model, all the seven parameters were mapped using Gis software. The Depth parameter (D) (Fig. 4a) showed that the highest values (45) are located in the south of Djelfa city, while the lowest ones (5 to 10) (representing the lowest depths) are distributed over the majority of the Mio-plio-quaternary aquifer. Recharge parameter (R) (Fig. 4b) in the considered region was determined basing on an only value which yielded a single index (4) that is considered as a very low value because it is related to rainfall distribution, slope, topographic relief [Jasem and Alraggad, 2010] and mainly to the potential evapotranspitation (PET) [Heiß et al., 2020] reaching $824.7 \mathrm{~mm}$ greater than raifall $(308.24 \mathrm{~mm})$. The Mio-plio-quaternary aquifer is formed by two hydrogeologic formations, the first one located in the central and thenotrh-eastern parts and composed by a mixture of sand, gravel and clay. The second one is formed by a mixture of clay, conglomerates and lacustrine limestone located in the rest of the aquifer (Fig. 4c). Soil parameter map (Fig. 4d) illustrates the distribution of soil particles size and texture of soil media [Jasem and Alraggad, 2010]. It shows that calcium soils cover the entire surface of the study area.T map alowed concluding that the characteristic slopes are between 0 and $12 \%$. The steep slopes ( 12 to $>18 \%$ ) represent a small area (Fig. 4e). The unsaturated zone represented by the Fig. $4 \mathrm{f}$ is composed by three geological formations; the first one formed by a mixture of sand, gravel and clay located in the central and the north-eastern part of our 


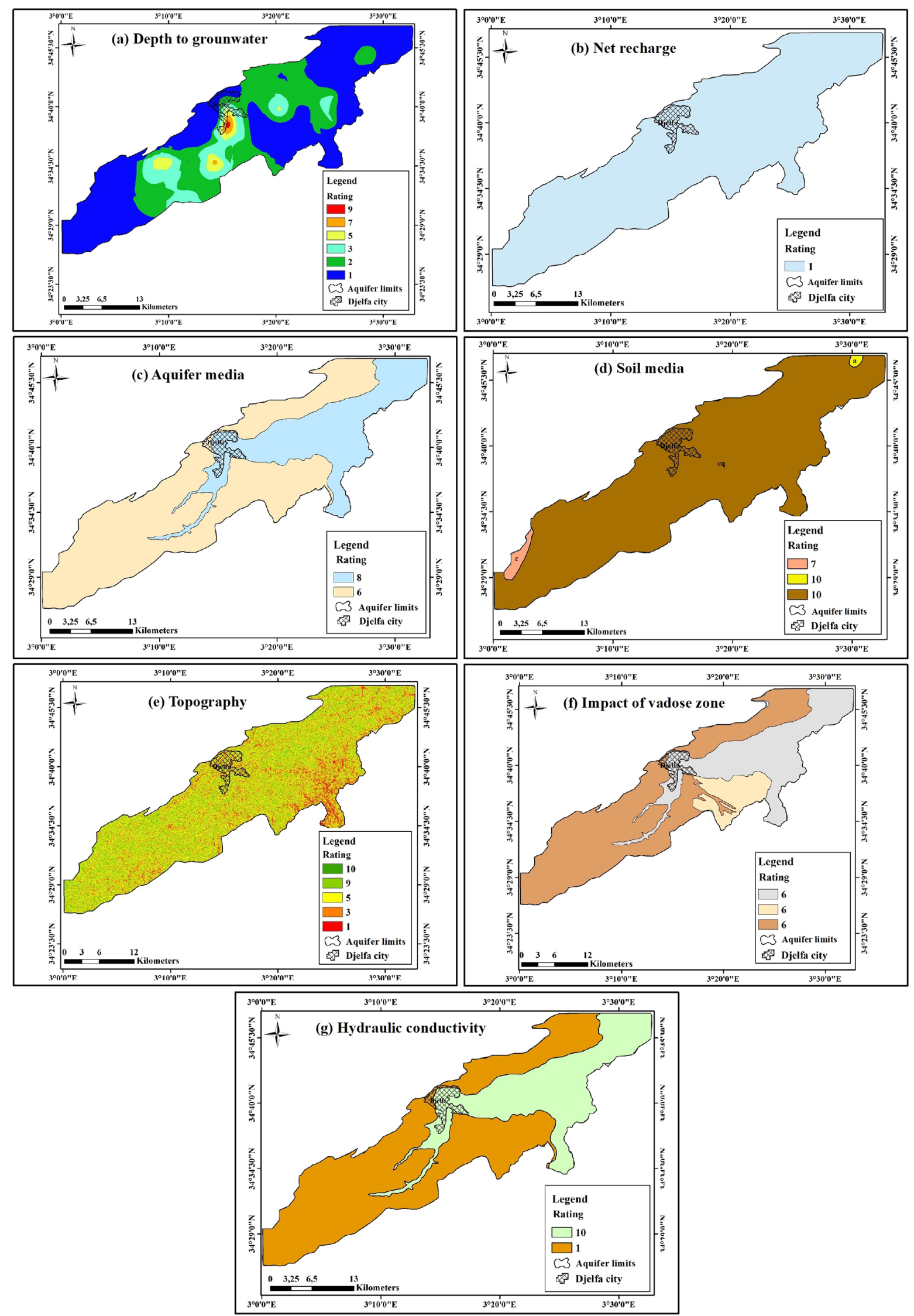

Figure 4. Rating maps of the DRASTIC parameters: Depth to groundwater (a), Net recharge (b), Aquifer media (c), Soil media (d), Topography (e), Impact of vadoze zone (f) and Hydraulic conductivity (g) 
aquifer, the second one by a limestone crust and ancient quaternary deposits located in the southern part and the last one by a mixture of clay, conglomerates and lacustrine limestone located in the rest of the aquifer. Fig. $4 \mathrm{~g}$ represents the Conductivity parameter (C) which is directly related to the hydrodynamic characteristics (flow rates, speed, hydraulic gradient). A proportional relationship between hydraulic conductivity and pollution exists. The highest conductivities are located in the central and north-eastern parts where the water table is formed by sand, gravel and clay mixture.

The vulnerability indices, thus determined, according to the DRASTIC method vary between 90 and 143. From the DRASTIC index values distribution map it is clear that the study area is concerned by two vulnerability classes (Fig. 5).

- The central and the south-western zones characterized by a low vulnerability $(<100)$ occupying an area of about $25.00 \%$ (Table 5 ).

- The north-eastern zone with an index varying between 101-140 characterizing a moderate vulnerability and representing $75.00 \%$ of the total aquifer area (Table 5).

Table 5. Spatial distribution of DRASTIC vulnerability classes

\begin{tabular}{|l|c|c|}
\hline \multicolumn{1}{|c|}{$\begin{array}{c}\text { Vulnerability } \\
\text { degree }\end{array}$} & $\begin{array}{c}\text { Vulnerability index } \\
\text { classes }\end{array}$ & $\begin{array}{c}\text { Areal coverage } \\
(\%)\end{array}$ \\
\hline Low & $<100$ & 25.00 \\
\hline Moderate & $101-140$ & 75.00 \\
\hline
\end{tabular}

\section{Water quality index (WQI)}

The main purpose of WQI computing is to verify the computed vulnerability indices [Heiß et al., 2020]. WQI was calculated based on twenty seven (27) groundwater samples during the wet period. The camputed values range from 60.33 to 260.52 (Table 6).

The highest values (representing the Very poor waters) are related to high total dissolved solids [Azlaoui et al., 2021] and representing 7\% of all samples. Good waters ranging from 50 to 100 represent $51.85 \%$. The rest is represented by the Poor Waters. It can be concluded that these waters are more or less acceptable for human consumption.

WQI spatial distribution (Fig. 6) show that the northern and the south-western parts of the Mioplio-quaternary aquifer are characterized by poor to very poor waters, while almost of the northeastern and southern parts have good waters. This explaines and confirms the exchanges between the geological formations and the groundwaters.

\section{Correlation betwwen vulnerability and WQI indices}

Several researchers have proposed the validation of vulnerabilty model by its correlation with natural or anthropogenic pollution [Jasem and Alraggad, 2010; Huan et al., 2012; Boufekane and Saighi, 2018; Satouh et al., 2021].Since the nitrate

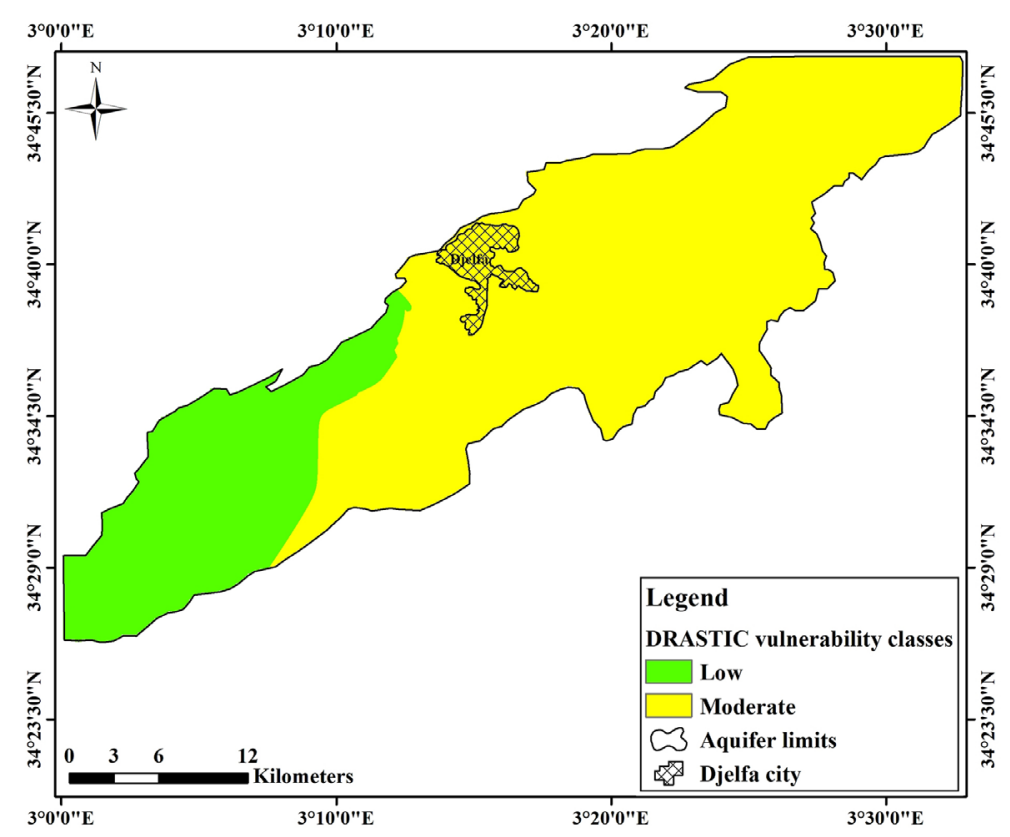

Figure 5. Distribution map of vulnerability index values 
Table 6. Calculated WQIs and their classification

\begin{tabular}{|c|c|c|c|c|c|c|c|c|c|}
\hline Sample & $X(\mathrm{~m})$ & $Y(\mathrm{~m})$ & $\begin{array}{c}\text { WQI } \\
(\text { April 2015) }\end{array}$ & Classification & Sample & $X(\mathrm{~m})$ & $\mathrm{Y}(\mathrm{m})$ & $\begin{array}{c}\text { WQI } \\
\text { (April 2015) }\end{array}$ & Classification \\
\hline F1 & 554506 & 151936 & 111.59 & Poor water & F15 & 549381 & 143273 & 92.78 & Good water \\
\hline F2 & 561120 & 154920 & 88.26 & Poor water & F16 & 549877 & 146796 & 79.37 & Good water \\
\hline F3 & 565543 & 157241 & 73.53 & Good water & F17 & 547148 & 149739 & 245.47 & Very poor water \\
\hline F4 & 561575 & 152019 & 135.48 & Poor water & F18 & 545867 & 148206 & 260.52 & Very poor water \\
\hline F5 & 569388 & 154050 & 100.77 & Poor water & F19 & 544461 & 145802 & 151.25 & Poor water \\
\hline F6 & 566411 & 154588 & 123.17 & Poor water & F20 & 545123 & 145097 & 116.46 & Good water \\
\hline F7 & 563683 & 153014 & 102.58 & Poor water & F21 & 534706 & 141906 & 195.84 & Poor water \\
\hline F8 & 558557 & 152185 & 68.39 & Poor water & F22 & 541072 & 143398 & 152.57 & Poor water \\
\hline F9 & 566329 & 150029 & 88.24 & Poor water & F23 & 539377 & 140414 & 80.23 & Good water \\
\hline F10 & 567982 & 149698 & 58.83 & Good water & F24 & 541113 & 137761 & 66.94 & Good water \\
\hline F11 & 566122 & 146341 & 67.99 & Poor water & F25 & 548554 & 141947 & 64.11 & Good water \\
\hline F12 & 558061 & 147542 & 69.28 & Good water & F26 & 553762 & 152060 & 125.05 & Poor water \\
\hline F13 & 555333 & 149200 & 113.71 & Good water & F27 & 549959 & 139792 & 60.33 & Good water \\
\hline F14 & 553390 & 146133 & 87.53 & Good water & & & & & \\
\hline
\end{tabular}

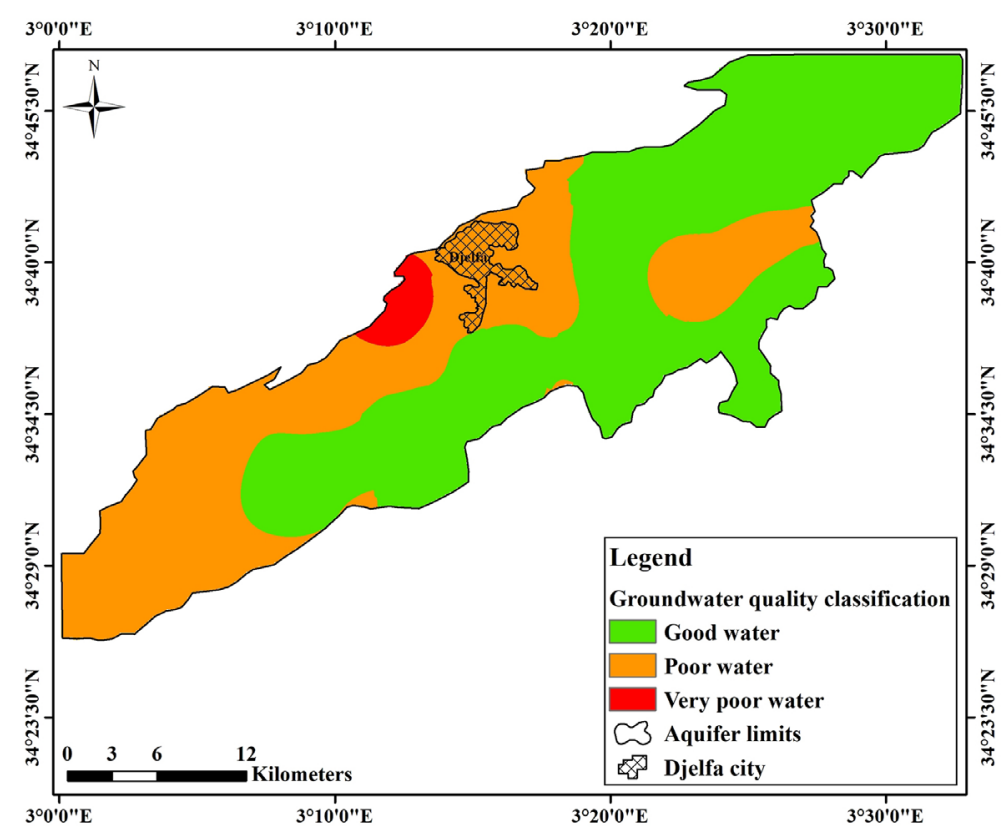

Figure 6. WQI spatial distribution during the dry period (April 2015)

concentrations of the 27 groundwater samples are below WHO standards $(50 \mathrm{mg} / \mathrm{l})$, DRASTIC model validation depend on its correlation with WQI [Heiß et al., 2020]. To this end, the Spearman rank correlation coefficient was used [Huan et al., 2012; Heiß et al., 2020]. It is a statistical measure of the strength of a monotonic relationship between paired data. The closest correlations to \pm 1 are the strongest. This coefficient revealed a low correlation $\left(W_{I} v_{V} D_{I}: 0.221\right)$ which is clearly remarkable in the comparison of Figs. 5 and 6 . Low vulnerability coincides with high and moderate groundwater pollution (poor to very poor water quality). It can be concluded that DRASTIC model does not match with groundwater pollution and cannot reflect it.

\section{Pollution risk evaluation}

The main idea in this paper, after evaluating groundwater vulnerability and hazard (i.e, water quality), was to evaluate the pollution risk. Since Wisner et al. (2004) defined the risk as the combination of vulnerability and hazard and can be formulated by the formula (6), the risk index can be calculated by multiplying vulnerability and 
hazard indices. Water quality index was assigned as hazard index, DRASTIC model represent the vulnerability index.

$$
R=H \times V
$$

where: $R$ is the risk, $H$ is the hazars,

$V$ is the vulnerability.

The risk index classified pollution risk into five levels as mentioned in Table 7.

The computed values of the risk index range from 6235.20 to 23446.80 . According to the risk map (Fig. 7) three levels of groundwater pollution risk have been observed ranging from low to high risk. The most dominant was the moderate risk occupying the largest area of the aquifer $\left(507.60 \mathrm{~km}^{2}\right)$. The second level is the low risk covering $216.00 \mathrm{~km}^{2}$. The high risk was very limited and located in the western part of Djelfa city $\left(32.40 \mathrm{~km}^{2}\right)$. On the basis of this map, it can be concluded that the risk index can allow decision

Table 7. Water pollution risk classification with respect to risk index

\begin{tabular}{|c|c|}
\hline Risk index & Level of risk \\
\hline$<5000$ & Negligible \\
\hline $5000-10000$ & Low \\
\hline $10000-20000$ & Moderate \\
\hline $20000-30000$ & High \\
\hline$>30000$ & Very high \\
\hline
\end{tabular}

makers and groundwater managers to better manage the groundwater resources by determining high risk areas which must be avoided in the installation of new boreholes.

\section{CONCLUSIONS}

The vulnerability assessment carried out using the DRASTIC model revealed a low to moderate vulnerability distributed from the south to the north respectively. However, the water quality evaluation realized based on WQI index showed a trend of good to very poor water. The distribution of this index was in contradiction with that of the vulnerability proving groundwater and geological formations exchanges.

The validation of the vulnerabilty model based on its correlation with water quality index allowed determining a low correlation which implies that this model cannot refelect the groundwater pollution.

On the basis of the assessment of the vulnerabilty and the water quality assigned as hazard, this study highlighted the determination of the Risk index. Its distribution map showed a dominance of low to moderate risk allover the studied aquifer excepting a very small area located in the west of Djelfa city recording a high risk.

Finally, regarding groundwater management, it can be said that the spatial distribution map of

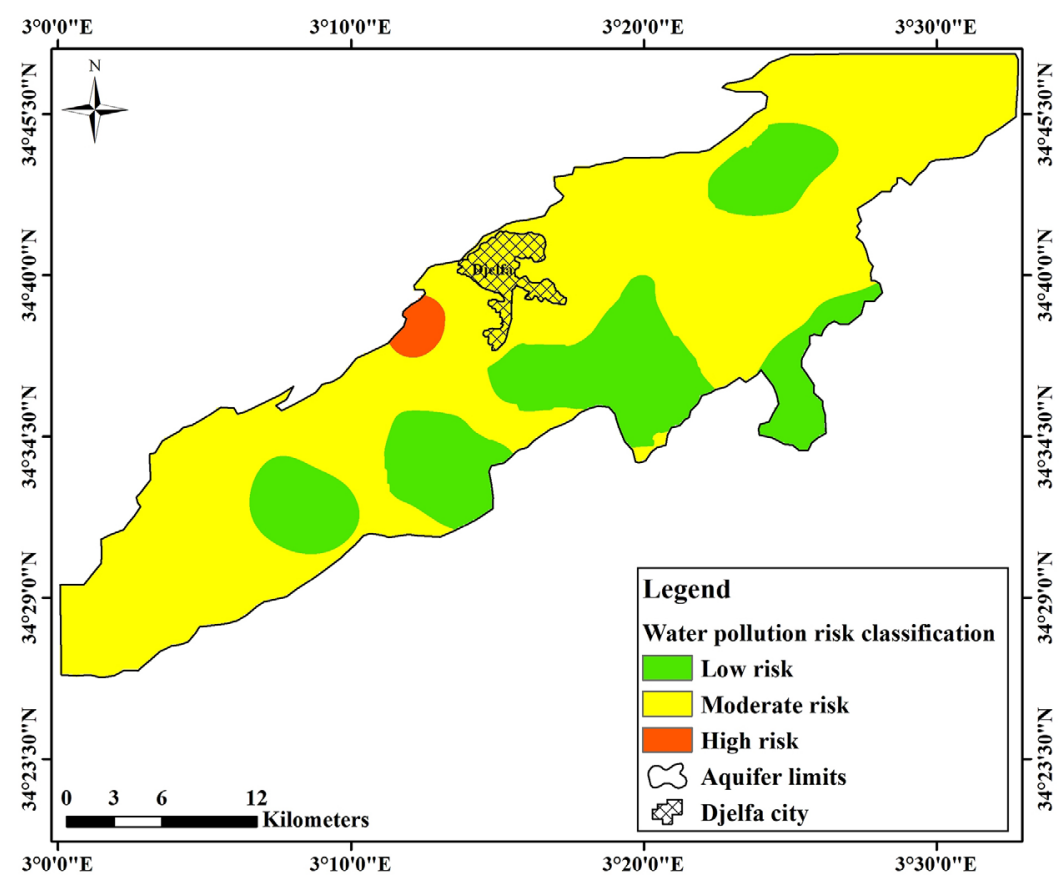

Figure 7. Risk map of the Mio-plio-quaternary aquifer of Djelfa syncline 
the risk index must be realized by decision makers and groundwater managers. Once done, the determined high risk areas, taking into account the socio-economic and environmental interests, must be avoided in the installation of new boreholes. Other works based on this risk index in other regions are essential to prove these results.

\section{REFERENCES}

1. Abassi S.A. 1999. Water Quality Indices. State-ofthe art. J.IPHE., 1.

2. Ali-Rahmani S.E., Chibane B., Boucefiène A. 2016. Groundwater recharge estimation in semi-arid zone: a study case from the region of Djelfa (Algeria). Applied Water Science, 7, 2255-2265.

3. Allechy F.B., Lasm T.H., Youan T.M., Yao K., Assemien F., Kouakou. O.S., Oka K.A.R., Baka D., De Lasme O.Z. 2016. Cartographie de la vulnerabilite à la pollution des aquiferes du socle precambrien : cas de la region d'Oume (Centre-Ouest de la Cote d'Ivoire) (in French). European Scientific Journal, 12, 20.

4. Aller L., Bennett T., Lehr J.H., Petty R.J., Hackett G. 1987. DRASTIC: a standardized system for evaluating groundwater pollution potential using hydrogeologic settings. EPA/600/2-87/035-USA: US Environmental Protection Agency.

5. Asadi S.S., Vuppala P., Anji R.M. 2007. Remote sensing and GIS techniques for evaluation of groundwater quality in Municipal Corporation of Hyderabad (Zone-V). India Int. J. Environ. Res. Publ. Health, 4(1), 45-52.

6. Azlaoui M., Zeddouri A., Haied N., Nezli I.E., Foufou A. 2021. Assessment and mapping of groundwater quality for irrigation and drinking in a semi-arid area in Algeria. Journal of Ecological Engineering, 22(8), 19-32.

7. Babiker I.S., Mohamed M.A.A., Hiyama T. 2007. Assessing groundwater quality using GIS. Water Resources Management, 21, 699-715.

8. Bharti N. \& Katyal D. 2011. Water quality indices used for surface water vulnerability assessment. International Journal of Environmental Sciences, 2(1).

9. Boufekane A. \& Saighi O. 2018. Application of Groundwater Vulnerability Overlay and Index Methods to the Jijel Plain Area (Algeria). Groundwater, 56(1), 143-156.

10. Brown R.M., McClelland N.I., Deininger R.A., Tozer R.G. 1970. Water quality index-do we dare? Water Sewage Works, 117(10), 339-343.

11. Chibane B., Boutaleb A., Lacroix M. 2010. Etude hydrochimique et Approche Isotopique en Région semi-aride: cas du Synclinal de Djelfa (Algérie) (in
French). European Journal of Scientific Research, 45(2), 270-290.

12. Chibane B. \& Ali-Rahmani S.E., 2015. Hydrological based model to estimate groundwater recharge, ealevapotranspiration and runoff in semi-arid area (in French). Larhyss Journal, 231-242.

13. Dwivedi S.L. \& Pathak V. 2007. A preliminary assignment of water quality index to Mandakini river, Chitrakoot. Indain J. Environmental Protection, 27, 1036-1038.

14. Engel B.A., Navulur, K.C.S., Cooper B.S., Hahn L. 1996. Estimating groundwater vulnerability to non-point source pollution from nitrates and pesticides on a regional scale. Int. Assoc. Hydrol. Sci., 235, 521-526.

15. Foufou A., Djorfi S., Haied N., Kechiched R., Azlaoui M., Hani A. 2017. Water pollution diagnosis and risk assessment of Wadi Zied plain aquifer caused by the leachates of Annaba landfill (N-E Algeria). Energy Procedia, 119(2017), 393-406.

16. Freeze R.A. \& Cherry J.A. 1979. Groundwater. Prentice-Hall, New Jersey.

17. Heiß L., Bouchaou L., Tadoumant S., Reichert B. 2020. Index-based groundwater vulnerability and water quality assessment in the arid region of Tata city (Morocco). Groundwater for Sustainable Development, 10(2020), 100344.

18. Horton R.K. 1965. An index number system for rating water quality. J. Water Pollu. Cont. Fed., 37(3), 300-305.

19. Huan H., Wang J., Teng Y. 2012. Assessment and validation of groundwater vulnerability to nitrate based on a modified DRASTIC model: A case study in Jilin City of northeast China. Science of the Total Environment, 440(2012), 14-23.

20. Jasem A.H. \& Alraggad M. 2010. Assessing groundwater vulnerability in Azraq Basin area by a modified DRASTIC index. J. Water Resource and Protection, 2, 944-951.

21. Ketata M., Gueddari M., Bouhlila R. 2012. Use of geographical information system and water quality index to assess groundwater quality in El Khairat deep aquifer (Enfidha, Central East Tunisia). Arabian Journal of Geosciences, 5, 1379-1390.

22. Khan A.A., Paterson R., Khan H. 2003. Modification and application of the CCME WQI for the communication of drinking water quality data in new found land and labrador. Presented at 38th, Central Symposium on Water Quality Research, Canadian Association on Water Quality 10-11 February 2003, Burlington, Canada.

23. Knox R.C., Sabatini D.A., Canter L.W. 1993. Subsurface transport and fate processes. Lewis Publishers, USA.

24. Krishan G., Singh S., Kumar C.P., Garg P.K., 
Gurjar S., Ghosh N.C., Chaudhary A. 2016. Assessment of groundwater quality for drinking purpose by using water quality index (WQI) in $\mathrm{Mu}-$ zaffarnagar and Shamli districts, Uttar Pradesh, India. Hydrology Current Research, 7(1), DOI: 10.4172/2157-7587.1000227.

25. Kumar K.S., Kumar C.S., Prrasad K.H., Rajesh B., Prasad R.S., Venkatesh T. 2015. Assessment of ground water quality using water quality index. International Journal of Innovative Research in Advanced Engineering (IJIRAE), 2(3), 103-108.

26. Mardhel V., Pinson S., Gravier A. 2005. Cartographie de la vulnérabilité intrinsèque des eaux souterraines en région Nord-Pas-de-Calais (in French). (BRGM/RP - 54238 - FR Décembre 2005).

27. Mitra B.K. 1998. Spatial and temporal variation of ground water quality in sand dune area of Aomori prefecture in Japan. 062023, 2006 ASAE Annual Meeting.

28. NRC. 1993. Groundwater vulnerability assessment: Predicting relative contamination potential under conditions of uncertainty. Committee for Assessing Groundwater Vulnerability, 210. Washington, DC: National Academy Press.

29. Pradhan S.K., Patnaik D., Rout S.P. 2001. Water quality index for the ground water in and around a phosphatic fertilizer plant. Indian Journal of Environmental Protection, 21, 355-358.

30. Ramakrishnaiah C.R., Sadashivaiah C., Ranganna G. 2009. Assessment of water quality index for the groundwater in Tumkur Taluk, Karnataka State. India. E-Journal of Chemistry, 6(2), 523-530.

31. Reza R. \& Singh G. 2010. Assessment of ground water quality status by using water quality index method in Orissa, India. World Appl. Sci. J., 9(12), 1392-1397.

32. Satouh A., Bouselsal B., Chellat S., Benaabidate L. 2021. Determination of groundwater vulnerability using the drastic method in Ouargla shallow aquifer
(Algerian Sahara). Journal of Ecological Engineering, 22(6), 12-19.

33. Şener Ş., Şener E., Davraz A. 2017. Evaluation of water quality using water quality index (WQI) method and GIS in Aksu River (SW-Turkey). Science of the Total Environment, 584-585, 131-144.

34. Srinivasamoorthy K., Chidambaram M., Prasanna M.V., Vasanthavigar M., John Peter A., Anandhan P. 2008. Identification of major sources controlling Groundwater Chemistry from a hard rock terrain-a case study from Mettur taluk, Salem district. Tamilnadu, India. Journal of Earth System Sciences, 117(1), 49-58.

35. Taabni M. \& El Jihad M.D. 2012. Eau et changement climatique au Maghreb: quelles stratégies d'adaptation? (in French). Les Cahiers d'Outre-Mer, Revue de Géographie de Bordeaux, 260, 493-518.

36. USGS (US Geological Survey). 2019. EarthExplorer. http://earthexplorer.usgs.gov. Accessed September 2019 .

37. Vasanthavigar M., Srinivasamoorthy K., Rajiv Gantha R., Vijayaraghavan K., Sarma V.S. 2010. Characterization and quality assessment of groundwater with special emphasis on irrigation utility: Thirumanimuttar sub-basin, Tamil Nadu, India. Arab .Geosci. J. DOI: 10 1007/s12517-010-0190-6.

38. Vrba J. \& Zaporozec A. 1994. Guidebook on mapping groundwater vulnerability. Int Contrib Hydrol, 16,131 .

39. WHO. 2011. Guidelines for drinking-water quality world health organization, 4th edn, Geneva, Switzerland.

40. Wisner B., Blaikie P., Cannon T., Davis I. 2004. At Risk, Natural hazard, people's vulnerability and disasters. 2nd edn. Routledge Taylor \& Francis Group, London and New York, 49-52.

41. Yidana S.M. \& Yidana A. 2010. Assessing water quality using water quality index and multivariate analysis. Environmental Earth Sciences, 59, 1461-1473. 